\title{
A CONDUTA ANTISSINDICAL DO SUPREMO TRIBUNAL FEDERAL: REFLEXÕES ACERCA DO RECURSO EXTRAORDINÁRIO 693.456/RJ
}

\section{THE ANTI-UNION CONDUCT OF THE SUPREME FEDERAL COURT: REFLECTIONS ON THE EXTRAORDINARY APPEAL 693.456 / RJ}

\author{
Renato de Almeida Oliveira Muçouçah \\ Mestre e Doutor em Direito pela Faculdade de Direito da Universidade de São Paulo \\ (USP). Professor da Faculdade de Direito da Universidade Federal do Rio de Janeiro \\ (UFRJ) e da Faculdade de Direito da Universidade Federal de Uberlândia (UFU). \\ E-mail: mucoucah@usp.br
}

Recebido em: 12/01/2016

Aprovado em: 03/05/2017

Doi: $10.5585 /$ rdb.v17i7.580

RESUMO: O presente estudo tem como objetivo analisar a conduta antissindical presente no Recurso Extraordinário 693.456/RJ, recentemente julgado pelo Supremo Tribunal Federal. Para tanto, parte-se para a análise da liberdade sindical como direito fundamental, tendo a greve como uma das possíveis formas de ação das entidades de representação obreira. Na sociedade salarial, em que praticamente todos sobrevivem por meio da remuneração oriunda de seu trabalho, a ausência de pagamento por parte do empregador enquanto seus subordinados exercem legitimamente o direito de greve retira a essência desse direito fundamental. Em análise mais detida acerca dos instrumentos normativos, da doutrina e da jurisprudência brasileiras, é possível constatar que a decisão tomada pela Corte Constitucional encontra-se eivada de antissindicalidade, em seu conceito mais amplo. Além disso, pretende-se estudar os desdobramentos do direito à liberdade sindical, e a maneira como tal instituto vem sendo tratado pelo Estado brasileiro, inclusive quanto ao direito de greve. Para tanto, buscou-se o estudo hipotético-dedutivo das questões existentes nas lacunas do direito brasileiro, via análise dedutiva de livros especializados na temática e as hipóteses de resposta por eles apresentada. Também se analisou, indutivamente, alguns julgados que guardam pertinência temática quanto ao tema. Lado outro, a dialética formal e o direito comparado permitiram que se chegasse a conclusões mais plausíveis quanto à antissindicalidade praticada pelo Estado no Brasil.

Palavras-chave: Direitos Fundamentais; liberdade sindical; conduta antissindical; direito de greve.

ABSTRACT: The present study aims to analyze the anti-union conduct present in Extraordinary Appeal 693.456 / RJ, recently judged by the Federal Supreme Court. To do this, the study starts with the analysis of freedom of association as a fundamental right, with the strike as one of the possible forms of action of workers' representation entities. In the wage society, where practically everyone survives by means of the remuneration derived from their work, the absence of payment by the employer while his subordinates legitimately exercise the right to strike removes the essence of this fundamental right. In a more detailed analysis of normative instruments, brazilian doctrine and jurisprudence, it is possible to verify that the decision taken by the Constitutional Court is fraught with anti-unionism, in its broadest concept. In addition, it intends 
to study the unfolding of the right to freedom of association, and the way in which such an institute has been treated by the Brazilian State, including the right to strike. To this purpose, was used sought the hypothetical-deductive study of the existing issues in the gaps of Brazilian law, via deductive analysis of specialized books on the subject and the alternative answers they submitted. Also analyzed inductively, some tried to keep thematic pertinence on the subject. Other hand, the formal dialectic and comparative law allowed to arrive at the most plausible conclusions regarding the anti-unionism practiced by the State in Brazil.

Keywords: Fundamental Rights; union freedom; anti-union conduct; right to strike.

SUMÁRIO: Introdução. 1. Liberdade sindical e direito de greve: breves considerações. 1.1. O conteúdo da liberdade sindical: um breve relato. 1.2. A liberdade sindical como direito fundamental. 2. Em busca do conceito de conduta antissindical. 3. Atos antissindicais contra o direito de greve: breves considerações acerca da apreciação, pelo Supremo Tribunal Federal, do Recurso Extraordinário 693.456/RJ. Considerações Finais. Referências Bibliográficas.

\section{INTRODUÇÃO}

No ordenamento jurídico brasileiro a liberdade sindical encontra-se elevada ao patamar de direito fundamental, além de ser umbilicalmente vinculada à questão democrática. Não por outra razão, as formas de tutela concebidas para coibir práticas atentatórias a tal preceito, as condutas antissindicais, devem ser as mais eficazes e tempestivas possíveis.

A greve, ou o exercício desse direito, ganha destaque no texto constitucional, embora pertença ao âmbito da ação sindical concreta. Todavia, em recente decisão (Recurso Extraordinário 693.456/RJ), o Supremo Tribunal Federal criou um gravíssimo obstáculo para o exercício do direito de greve no serviço público: deverá a Administração Pública cortar o salário de servidores que participarem de movimentos paredistas enquanto estes perdurarem.

O Supremo Tribunal Federal, referendando a visão maniqueísta da doutrina e da jurisprudência que veem, na greve, o "mal" a ser combatido (pois é conflitiva), contrapondo-se ao "bem" representado pela negociação coletiva (quando ocorre pacificação nas relações entre capital e trabalho), cria obstáculos ao exercício do direito de greve, ordenando que se deixe de pagar salários a quem estiver em greve. Por outro lado, remete à possibilidade de negociação coletiva a discussão quanto ao pagamento retroativo desses dias de paralisação, com indevida ingerência na ação sindical, vez que acaba por forçar o ente representativo dos trabalhadores em concluir, o quanto antes, sem aprofundada discussão, o processo negocial, dentre outras questões.

Tal decisão afronta postulados básicos da liberdade sindical e, por isso, refletem seu contraponto: a conduta antissindical. Todavia, esta conduta é agora levada a termo pelo Poder Judiciário, em sua mais alta cúpula, de forma a prejudicar a luta de um sem-número de servidores públicos brasileiros que, por razões adiante discutidas, sentir-se-ão intimidados em não aderir a qualquer movimento grevista.

Desta feita, o presente trabalho insere-se no questionamento de avaliar não apenas os atos tendentes a desestabilizar, suprimir, negar ou sublimar a liberdade sindical em casos já previstos nos mais diversos diplomas jurídicos, mas de considerar tais condutas como atentados à própria concepção de liberdade sindical em sentido amplo. Afinal, se as decisões com repercussão geral do Supremo Tribunal Federal vinculam o administrador, deve-se avaliar com a devida cautela a decisão tomada acerca do direito de greve e sua relação com o direito à liberdade sindical, que, no presente caso, aparenta ter sofrido prática antissindical pelo próprio Poder Judiciário. 
Por ser tema cujo estudo demanda conhecimentos de direito constitucional, trabalhista e, em certa medida, direito internacional, o tratamento dedutivo da pesquisa bibliográfica analisará obras acerca do tema proposto; haverá, ademais, a análise indutiva de julgados e posições do Supremo Tribunal Federal e do Tribunal Superior do Trabalho, anteriores ao Recurso Extraordinário em comento, acerca de assuntos relacionados ao tema estudado. Buscarse-á apresentar respostas quanto às lacunas encontradas em teste dedutivo de hipóteses (método hipotético-dedutivo), máxime no que respeita à amplitude da liberdade sindical. Também o direito comparado, por meio da dialética formal, poderá trazer subsídios para a análise dos resultados apresentados como tentativas de resposta ao problema aventado.

\section{LIBERDADE SINDICAL E DIREITO DE GREVE: BREVES CONSIDERAÇÕES}

Não muitas palavras encontram signos ambíguos em nossa língua como trabalho, vernáculo referente até mesmo ao mundo da natureza, cego a valores. Na atividade dos homens, entretanto, o vocábulo significa a aplicação de uma força impulsiva à produção, ou seja, à realização de uma finalidade humana. Inseparável de seu agente (que planeja, pensa, age e trabalha), o trabalho confunde-se com a própria personalidade do homem, constituindo-se numa verdadeira mônada de valor (MORAES FILHO, 1956b, p. 66-69).

No alvorecer da Revolução Industrial, operou-se uma mudança de lógica. O consumidor não precisaria mais viajar até o encontro do produto; ao contrário: o produto passou a ir ao encontro do consumidor. A produção em massa e a possibilidade de lucro incessante, sem depender mais das vicissitudes várias da natureza, engendraram necessidade de segurança e liberdade. Qualquer movimento em contrário deveria ser sumariamente reprimido, especialmente o direito de greve.

De fato, os movimentos grevistas antecederam a própria noção de sindicato e, com maior acerto ainda, o ideário da liberdade sindical. O Código Penal de 1890 conheceu os movimentos "paredistas" bem antes da sindicalização, criminalizada no artigo 206 do digesto penal da recém-instaurada República (SILVA, 2009, p. 15-16).

A Lei Le Chapelier, de 1791, é paradigmática no sentido exposto: demonstrava ojeriza aos grupos profissionais corporativos, porque admiti-los significaria controle de produção, monopólio, direção, limite, rotina, medo do futuro, etc.; liberdade deveria ser a palavra de ordem, sem interferência de grupos ou do Estado na economia. Seria este o estímulo na produtividade e na autogestão do capital. A proteção a tal ideologia mereceu a majestade da tutela penal; nesse diapasão, veja-se o Código Penal Napoleônico de 1810, que punia com prisão e multa qualquer tentativa de coligação dos operários, seja para fazer cessar o trabalho, seja para impedi-lo (MORAES FILHO, 1956a, p. 8-9). Como se nota, as relações entre capital e trabalho sempre foram tensas, pois os interesses eram antagônicos: o capital desejava valorização, conseguida apenas pela redução de custos de produtividade; os trabalhadores, ao revés, buscavam no mais das vezes apenas a sua reprodução material.

Dentro do modelo produtivo advindo com a revolução industrial, os trabalhadores vivenciaram três formas de integração ao longo da História. A primeira delas foi a condição proletária; esse período se caracteriza pela exclusão dos trabalhadores em relação ao próprio tecido social: o proletário não existia para a sociedade porque apenas produzia para ela. Era tão miserável que não poderia sequer tornar-se consumidor. Logo, essa condição jamais permitiu com que se formasse alguma identidade de classe para que obreiros, em conjunto, lutassem por direitos.

Escolhida a lógica do capital, que subordina aquele que tem a força de trabalho em face de seu tomador, no afã de tecer uma espécie coesão social, advém, entre os trabalhadores, alguma identidade de classe (ROMAGNOLI, 2001, p. 20). Consoante assertiva de Robert Castel (1998), existe a passagem à condição operária dos trabalhadores, no momento em que a remuneração 
não se consubstancia apenas na retribuição pontual diretamente paga pelos serviços efetuados. Por meio do salário conquistam-se direitos como aposentadoria, auxílio por moléstia, bem como se propicia aos trabalhadores alcançar o mercado consumerista, o acesso à instrução formal, ao lazer, à propriedade, dentre outros.

Assim, a conquista do direito do trabalho, mas não apenas dele, ou somente a ele restrito, foi alcançada em razão da desobediência civil, estando presentes as ilícitas agremiações de trabalhadores, suas lutas reivindicativas e os movimentos grevistas. Em razão destes mesmos movimentos, passou-se a crer que entre patrões e empregados praticamente tudo seria possível e nem tudo estaria previamente delimitado. $\mathrm{O}$ acesso do proletariado a mais bens de consumo, serviços e direitos tornou-se apenas uma questão negocial, a depender da capacidade de coesão entre os trabalhadores, o que passou a dar-se na esfera sindical.

O empregador sempre representou, por si só, um ser coletivo obreiro: suas diretivas ganham repercussões não apenas em cada contrato de emprego individualmente considerado, mas também em todo o ambiente do trabalho. Somente pela coalizão de forças seria possível promover um diálogo direto e equivalente àquele que, por si só, coletivamente se impõe (SIQUEIRA NETO, 2000, p. 57). Esta é a premissa básica para a existência das associações de trabalhadores.

\subsection{O conteúdo da liberdade sindical: um breve relato}

O sindicalismo foi destes fatos históricos que do delito passou à tolerância, e nela logrou tornar-se direito. Mais ainda: direito fundamental. A pacificação desejada pelas partes contratantes trabalhistas encontrou num primeiro momento a força coercitiva do Estado como única confidente à sua possibilidade de concretizar-se.

As lideranças políticas sindicais, inicialmente tidas como ameaçadoras do poder estatal, neste sentido também contribuíram com a ojeriza aos atos sindicais (SILVA, 2006, p. 208). O Estado deixou de considerar o sindicalismo um delito; há muito já se previa a liberdade de trabalho, mas somente na segunda metade do longo século XIX iniciou-se o processo terminativo da fase de proibição associativa.

O tema ganhou projeção internacional com a Convenção 87 da OIT, até hoje não ratificada pelo Brasil. Finalmente vem a admitir-se, nesta primeira etapa evolutiva, o sindicato como pessoa jurídica de direito privado. A liberdade sindical constitui-se em direito das pessoas e das organizações, respectivamente em viés individual e coletivo perante o Estado, na classificação proposta por José Francisco Siqueira Neto (2000): há a faculdade de criar sindicatos, filiar-se ou não a estes, participar de suas atividades ou, enfim, de desfiliar-se, tudo sob a óptica individual. Coletivamente, a liberdade sindical nesta primeira fase constitui-se na autonomia grupal, com vistas a organizar internamente o sindicato, bem como formular e aplicar seu programa de ação.

A doutrina clássica europeia considera atentados à liberdade sindical a discriminação do trabalhador, quer por filiarem-se ou recusarem filiação a determinado sindicato, quer pelo fato de empregados valerem-se dos mais variados meios de ação sindical. Fala-se também da liberdade sindical em seu sentido coletivo, não cabendo ao Estado interferir na constituição e funcionamento da agremiação, sendo-lhe assegurada plena autonomia. Bem por isso, aliás, temse como atentado a esta liberdade a tentativa do Estado e/ou do empregador em domesticar e controlar ações obreiras (CAMERLYNCK; LYON-CAEN, 1972, p. 370-377).

De forma bastante genérica, esse é o discurso e também é a construção conceitual do signo de liberdade sindical, culturalmente difundida em países europeu, com maior ou menor detalhamento do que poderá ser considerado ato ou omissão violadores dessa liberdade. Na Itália (SCOGNAMIGLIO, 2005, p. 231), por exemplo, para além das linhas-mestras já sucintamente descritas, proíbe-se expressamente tratamento salarial diferenciado entre pessoas que participem 
ou não de atividades sindicais (como a greve). Na Espanha, a discussão centra-se mais na alta ou baixa representatividade do sindicato, para além da análise de legalidade ou não de determinadas ações sindicais, que poderão justificar até mesmo a demissão de algum trabalhador (ALONSO OLEA, 2009, p. 1292-1303). Em ambos os países tanto servidores públicos quanto trabalhadores da iniciativa privada têm tratamento igual no que concerne a direitos sindicais.

Tal como nos países acima citados, também em Portugal há pluralidade sindical (e não unicidade, como ocorre no Brasil, em que apenas um ente é o responsável por representar os interesses de determinada categoria). Entre os lusitanos, busca-se ressaltar a proibição de filiação em dois sindicatos diferentes, no afã de escolher qual convenção coletiva de trabalho virá a reger seu contrato (ou pedir que ambas sejam obedecidas concomitantemente pelo empregador). Também se fala em possível interferência indevida do Estado, quando limita a quatro anos o mandato do dirigente sindical, com possibilidade de uma recondução (FERNANDES, 2014, p. 636-637).

Todas essas questões geram discussões também no Brasil. Um país pode garantir a liberdade de associação sindical e, no entanto, conceder liberdades que, no plano fático, o Estado controle com olhos múltiplos e mãos firmes: no Brasil, por exemplo, desde a Constituição de 1891 é considerado lícito a todos associarem-se livremente, mas nem sempre a liberdade sindical existiu, conforme Amauri Mascaro Nascimento, Sônia Mascaro Nascimento e Marcelo Mascaro Nascimento (2015, p. 77). Liberdade sindical somente pode comungar com valores democráticos, sendo estes o próprio fundamento para a existência de sindicatos. Limita-se, pois, o poder estatal, a fim de que a Administração não venha desnaturar ou desvirtuar o direito de livre associação das pessoas, bem como a organização sindical interna e suas formas de ação, incluindo-se a greve.

Observe-se que o empregador é um destinatário sempre imediato das investidas sindicais. Logo, a força e o peso do Estado devem agir não apenas na direção de reconhecer aos trabalhadores o direito de associação, abstendo de imiscuir-se em assuntos que não lhe são próprios. Devem proteger o direito de associação sindical, sob a ótica individual e coletiva, das influências do empregador e de seu poder diretivo. $\mathrm{O}$ empregado, individualmente considerado, não poderá sofrer represálias quaisquer pelo fato de participar ou não da vida sindical, seja em qual nível ou esfera efetivamente desejar contribuir. Ademais, também os empregadores não poderão manipular, controlar ou desvirtuar, por qualquer meio, a entidade representativa dos interesses obreiros.

Justifica-se então o surgimento, em âmbito internacional, de normas assecuratórias de proteção contra condutas antissindicais, vez que referidas condutas buscavam aniquilar atividades destinadas a promover a interlocução social dos trabalhadores. A temática ganha importância pelo fato de a antissindicalidade consubstanciar-se na negação mais direta e pontual à liberdade sindical.

Não se pode incorrer no exagero de cogitar que qualquer ato antagônico do empregador em relação ao sindicato é, de per si, antissindical: as relações entre capital e trabalho são díspares, justamente por tais fatores representarem interesses diversos. Negociações e acordos não se fazem entre iguais, mas entre diferentes, com base em objetivos comuns. Neste estuário temático, encontra-se a Convenção 98 da OIT, já ratificada pelo Brasil e em vigor no direito interno do país.

No entanto, a proteção da liberdade sindical contra atos do Estado e do empregador não garante, por si só, a efetividade da interlocução social em todas as esferas de interesse dos trabalhadores, sobretudo quando o Estado faz as vezes de empregador. Está-se a falar, por óbvio, dos servidores públicos.

A liberdade sindical pode ser encarada também como direito à ação sindical. Valorizase a negociação coletiva, a participação (formal ou informal) dos sindicatos em órgãos públicos nos quais se promovam políticas que digam respeito às aspirações da classe, e, enfim, o reconhecimento de que a atividade sindical também inclui o exercício do direito de greve, 
inclusive na Administração Pública. Neste sentido, pois, são as Convenções da OIT de número 135, sobre as facilidades a serem dispensadas aos representantes dos trabalhadores na empresa, e a de número 154, sobre a promoção da negociação coletiva, que devem ser aplicadas também aos servidores públicos. Ademais, menciona-se a Convenção 151 e Recomendação 159 da OIT, que discutem negociação coletiva de trabalho no setor público.

Obviamente a liberdade sindical não é um direito absoluto. Encontra limitações, as quais devem ser justas e razoáveis, dentro dos princípios que decorrem da própria conceituação desta liberdade, ou ainda de outros (em regra, preceitos de ordem pública, ou seja, que representem a segurança e integridade do próprio Estado e de seus cidadãos). Assim se dá, por exemplo, a proibição de sindicalização para certos setores do funcionalismo público, em geral das Forças Armadas.

Por tratar-se de direito fundamental, os contornos das limitações acima citadas devem ser os mais restritivos possíveis: os servidores públicos devem ter garantido o direito à greve, à exceção daqueles que exercem funções de autoridade em nome do próprio Estado. Mesmo quanto a estes, não se lhes pode negar a possibilidade de reivindicação; deve ser garantida, ao menos, a possibilidade de negociação coletiva de forma facilitada e ágil, para compensar a proibição ou limitação do exercício das liberdades sindicais (VALTICOS, 1977, p. 249).

A restrição também deve ser verificada pelos países quanto à conceituação do que é tido como serviços essenciais, na esfera privada ou pública, considerados como aqueles que poderiam pôr em risco a vida, a segurança ou a saúde de toda a população, ou de grande parte dela.

Em relação a estes grupos, a restrição do direito à greve deveria vir acompanhada de mecanismos ágeis e imparciais de conciliação e arbitragem, para rapidamente solucionar conflitos (GERNIGON; ODERO; GUIDO, 1998). De qualquer maneira, os vários matizes da liberdade sindical são reciprocamente dependentes, sendo impossível pensá-la senão com a observância de todas estas dimensões, a fim de se encontrar um sistema que verdadeiramente promova a defesa dos interesses coletivos dos trabalhadores.

\subsection{A liberdade sindical como direito fundamental}

Como princípio absoluto, a dignidade da pessoa humana norteia as ações em todas as esferas da vida privada e pública, tanto do indivíduo quanto da coletividade. E a valorização do trabalho humano, como direito e princípio fundamental, é, na visão de Tércio Sampaio Ferraz Júnior, Maria Helena Diniz e Ritinha A. Stevenson Georgakilas (1989, p. 45),

[...] um repúdio à automação ou à animalização do sistema de produção, a um processo que se rejeita por motivos alheios a si mesmo, uma espécie de repetição compulsória de atividades que cessam apenas para o homem comer, dormir e recuperar as forças. Não é um repúdio à máquina ou ao animal, mas à maquinalização e animalização da atividade laboral do homem.

A Constituição não se funda apenas na nomenclatura trabalho humano, mas na valorização deste. Logo, ainda que haja trabalho humano no qual não se respeite este fundamento, a democracia será tida como farsa. Trabalho que não promove a dignidade humana desvaloriza esta atividade. Bobbio (2004, p. 45), aliás, demonstra preocupação para com direitos fundamentais: não é saber ao certo a natureza ou o fundamento destes, mas pensar formas para que eles não mais sejam sistematicamente violados.

No que concerne aos direitos sociais, conforme Flávia Piovesan (2006), estes merecem tanto respeito quanto os civis e políticos, sendo também exigíveis no plano pragmático. Ora, se os direitos de liberdade são autoaplicáveis, os de igualdade devem apresentar realização progressiva, posto estarem condicionados à atuação do Estado, o qual deve valer-se de todos os meios bastantes para efetivá-los em plenitude. Neste particular, é equivocada a ideia de que quanto aos 
direitos sociais só se poderia exigir do Estado prestações positivas; deve-se nestes direitos exigir, também, prestações negativas ou a mera abstenção estatal.

Parece ser inegável que os direitos sociais, também denominados como direitos de segunda dimensão (ou geração), possuem a marca da fundamentalidade. Seu conteúdo é a busca paulatina pela igualdade real, fática e concreta entre os cidadãos. Não se trata, pois, do culto liberal, que enxerga objetividade nos direitos civis e políticos, mas subjetivismo nos direitos sociais. Também os direitos de segunda dimensão (dentre os quais se inclui a garantia da liberdade sindical, para além de direitos individuais dos trabalhadores) requerem o Estado como "um artífice e um agente de suma importância" (BONAVIDES, 2016, p. 581) para que sejam concretizados. Trata-se de direitos garantidos aos trabalhadores como reconhecimento de sua dignidade coletiva.

O homem, embora seja indivíduo, vive e "se realiza concreta e dialeticamente na comunidade" (SOUZA, 2015, p. 92); por isto é que também existe a dignidade coletiva ou social: a ordem jurídica deve ser objetivamente respeitada pelos atores sociais nesse pacto ético firmado pela Constituição Federal de 1988. Justamente por isso a liberdade sindical possui vertentes de garantia individual e coletiva destinadas, num só tempo, a todos os membros de uma comunidade permeada por diversas normas.

A Constituição Federal de 1988 prevê a existência de direitos fundamentais sociais, tendo estes a mesma importância destinada aos direitos civis e políticos. Questões de liberdade sindical, como proibição de interferência do Estado ou do empregador em atividades sindicais e de representação obreira, além do reconhecimento do direito de greve, não são apenas normas constitucionais, mas também direitos fundamentais reconhecidos pelo Estado, que vinculam entes públicos e particulares à sua observância e concretização (MENDES; BRANCO, 2015, p. 648650). As tensões entre capital e trabalho, que resultam do conflito de classes, são reconhecidas e, mais ainda, juridicamente tuteladas com a marca da fundamentalidade: a liberdade sindical demonstra e prova que a classe trabalhadora tem o direito de reunir-se em agremiações no afã de, organizadamente, defender seus direitos em face de quem detém os meios de produção, com as ações que julgar mais conveniente.

$\mathrm{O}$ reconhecimento dos antagonismos de classe engendra, àqueles que vivem do trabalho, a possibilidade de lutar por direitos valendo-se da agremiação profissional (sindicato), que deve gozar de plena autonomia e independência para estabelecer, com o patronato, garantias que deverão ser obrigatoriamente respeitadas nas relações de trabalho (SILVA, 2008, p. 84-85). Os diplomas negociais (acordo e convenção coletiva de trabalho) são a síntese da constante luta pelo equilíbrio entre capital e trabalho e, por tal razão, a conduta antissindical é um grave atentado também à democracia: em não havendo liberdade na ação sindical obreira, as normas pactuadas entre capital e trabalho restarão tisnadas.

A liberdade sindical encontra-se consagrada no artigo $8^{\circ}$, caput, da Carta Magna, integrando um complexo rol de direitos fundamentais, todos reciprocamente complementares (SILVA, 2006, p. 208-209). Tal direito também resta assegurado pelo artigo $8^{\circ}, \S 1^{\circ}$, itens 1 e 3 , do Pacto Internacional de Direitos Econômicos, Sociais e Culturais, adotado pela Resolução 2.200-A da Assembléia Geral das Nações Unidas, em 16 de dezembro de 1966 que, no Brasil, foi aprovado pelo Decreto Legislativo 226/91, entrando em vigor em 24 de fevereiro de 1992, conforme Decreto 591/92.

Assim, a liberdade sindical, como nunca antes, foi alçada à categoria de direito fundamental, estando proibido o seu retrocesso. Relembrando, todavia, o oportuno questionamento de Bobbio, já citado, não basta enunciar direitos, e sim torná-los verdadeiramente efetivos, no exato sentido que os movimentos operários europeus do século XIX lograram imprimir-lhes. Cabe, porém, uma indagação última: pode-se afirmar que, verdadeiramente, existe liberdade sindical no Brasil? 
A resposta não é simples e tampouco comporta uma única versão. De fato, com o advento da Constituição Federal de 1988, nunca a liberdade sindical esteve tão plenamente garantida no país. Alguns resquícios de períodos autoritários, porém, remanesceram. No Brasil existe o regime da unicidade sindical, ou seja, restringe-se a representação dos trabalhadores e também dos empregadores a apenas um sindicato existente em determinada base de atuação (nunca inferior à área de um município).

Opõe-se a este conceito a pluralidade sindical, aparentemente mais democrática, pois se permite que, na mesma base territorial, haja mais de um sindicato representando pessoas ou atividades que tenham um interesse coletivo comum. Tal sistema, defendido pela OIT (Organização Internacional do Trabalho) em sua Convenção 87, é adotado pela maior parte dos países do mundo. No Brasil, o artigo $8^{\circ}$ da Constituição disciplina a liberdade sindical compatibilizando-a com o sistema da unicidade, o que, aparentemente, poderia soar contraditório.

José Carlos Arouca (2012), defensor do modelo constitucional de 1988, argumenta que o estabelecimento da pluralidade sindical acabaria por estabelecer critérios mediante os quais um sindicato seria tido como o mais representativo, e o risco de este ser assediado pelo empregador seria maior que no atual modelo. Por tais motivos, propõe a unicidade relativa: não haveria qualquer obstáculo legal para que existissem várias associações de trabalhadores, mas apenas uma delas os representasse. Se uma das associações lograsse provar que possui, a qualquer tempo, a maior parte da adesão por parte dos trabalhadores, atrairia seu reconhecimento como representante dos trabalhadores em detrimento do antigo sindicato, que perdeu representatividade.

Observe-se que o grande mote existente na discussão acerca da liberdade sindical é mensurar como e de que maneira atores estranhos ao ente de representação (seja o Estado, seja o empregador) poderiam afetar sua independência. A antissindicalidade e a liberdade sindical são verso e reverso da mesma medalha. Proteger os sindicatos de condutas antissindicais é, acima de tudo, defender sua autonomia para atuar como verdadeiro representante de interesses classistas.

\section{EM BUSCA DO CONCEITO DE CONDUTA ANTISSINDICAL}

Pouco valor teria em elevar-se a liberdade sindical como direito fundamental sem prever meios bastantes para garantir sua eficácia. Não apenas o empregador, mas também o Estado poderá promover condutas antissindicais ${ }^{1}$. No período anterior a 1988, o Poder Público lançava mão (sub-repticiamente) de tais expedientes. Havia a interferência do Estado nas organizações sindicais, de maneira a amoldar-lhes a própria administração, e também estatuir privilégios a

\footnotetext{
${ }^{1}$ A questão persiste atual. Em 1999 o Supremo Tribunal Federal julgou, em sede de Recurso Extraordinário, que o artigo 522 da CLT foi recepcionado pela Constituição Federal: "EMENTA: CONSTITUCIONAL. TRABALHO. SINDICATO: DIRIGENTES: CLT, art. 522. RECEPÇÃO PELA CF/88, art. 8*, I. O artigo 522, CLT, que estabelece número de dirigentes sindicais, foi recebido pela CF/88, art. $8^{\circ}$, I. II. - R.E. conhecido e provido". Conforme o relator, Ministro Carlos Velloso, "estabelece a Constituição estabilidade para os dirigentes sindicais. Seria possível, então, a lei disciplinar a matéria, em termo de número de dirigentes sindicais? Penso que sim. Caso contrário, podendo o sindicato estabelecer o número de dirigentes, poderia estabelecer número excessivo, com a finalidade de conceder-lhes a estabilidade sindical do art. $8^{\circ}$, VIII, da C.F., e art. 543, § 3, CLT". RECURSO EXTRAORDINÁRIO 193.345/SC, STF. Publicado no Diário de Justiça em 28.05.1999. Em verdade, com tal decisão o Colendo Tribunal engessa a atuação sindical, por não levar em consideração as peculiaridades de cada ente sindical. Muitas vezes, em razão de necessidades tais como a grande extensão territorial representada, ou ainda um número considerável de potenciais trabalhadores a serem representados, a entidade sindical ver-se-á obrigada em organizar-se com uma quantidade maior de dirigentes sindicais, para melhor desenvolvimento e operacionalização das atividades. Seria de bom alvitre que tal assunto fosse tratado pelos estatutos sindicais, porquanto eventuais e hipotéticos abusos perpetrados por parte das entidades poderiam ser sanados por via judicial, sempre que o número de dirigentes fosse desproporcional à sensata e real necessidade do sindicato. Neste sentido, ver DELGADO, 2016, p. 1482-1483. A rigor, é sustentável a tese de que a decisão ora comentada, no limite, pode constituir prática antissindical por parte do Estado.
}

Revista de Direito Brasileira | São Paulo, SP | v. 17 | n. 7 | p. 358 - 377 | Mai./Ago. 2017 
empregados sindicalizados, em face da admissão de trabalhadores em empresas que explorassem recursos públicos, no que concerne à concorrência para aquisição de moradia por meio do Plano Nacional de Habitação. Tal preceito é francamente contrário à liberdade de o empregado filiar-se ou não a um sindicato. O próprio artigo $8^{\circ}$ da Constituição Federal, ao preservar o sistema de unicidade sindical, teve semelhante significação, ao não garantir o pleno exercício da liberdade de escolha do trabalhador dentre possíveis sindicatos que poderiam representá-lo, conforme já visto.

Também a própria organização sindical poderá promover atos antissindicais, embora tal pareça estranho. Quando há pluralidade sindical, o que não é realidade no Brasil, o sindicato "A" poderia aliar-se ao empregador, prejudicando representantes ou empregados filiados ao sindicato "B", em virtude de uma razão qualquer (ser o sindicato mais "dócil" às investidas patronais, por exemplo).

De qualquer maneira, importa ter-se em mente que a conduta antissindical é nula de pleno direito. No entanto, em não sendo possível reparar o que tal conduta provocou ao obreiro (como no caso de inclusão do trabalhador em listas negras, por suas atividades sindicais), devese ressarcir patrimonial e moralmente o trabalhador quanto a qualquer prejuízo por ele sofrido (ECHEVERRIA, 1987, p. 152).

A tutela, pela própria relevância do bem jurídico, necessita ser pronta, ágil e eficaz: como neste rito não é possível estabelecer uma fase executiva, seria interessante um sistema de coação indireta para obrigar o condenado a cumprir a ordem judicial e, sobretudo, medidas preventivas a fim de se evitar novas práticas antissindicais.

A conduta ou prática antissindical possui diversas significações nos mais diferentes ordenamentos jurídicos e, bem por isso, não possui definições que possam exaurir seu conteúdo com definição precisa. Em regra, é na análise do caso concreto que se chega à conclusão se determinada prática é ou não antissindical, por traduzir-se em conduta atentatória à plena efetivação da liberdade sindical.

Em feliz tentativa de conceituar ato antissindical, Raquel Betty de Castro Pimenta (2014, p. 57-58) sintetiza que "o prefixo 'anti' traz a ideia de contrariedade, oposição. E é exatamente no sentido de violação à liberdade sindical que deve ser lida a expressão. [...] O termo 'sindical' deve ser interpretado em sua forma mais ampla", ou seja, deve ser direcionado não apenas às tentativas que obliterem as ações dos entes sindicais, mas também organizações de trabalhadores que, embora não constituídas como entes de representação, defendam interesses coletivos dos trabalhadores.

Um conceito bastante difundido acerca do tema remonta à ideia de foro sindical que, em verdade, não define a conduta, mas é a ela contraposta, como medida de proteção contra discriminação antissindical. Constitui-se em medida de combate discriminatório quanto aos dirigentes sindicais (pessoas que, de forma mais enfática e direta, promovem o contraponto de interesses àqueles dos empregadores em geral). As prerrogativas aos poucos lograram ser estendidas também a outros empregados que, mesmo não sendo especificamente dirigentes sindicais, desenvolvam ações neste sentido, como se vê, exemplificativamente, na Convenção 135 da OIT (garantias de proteção aos representantes de trabalhadores na empresa).

O âmbito da proteção não se restringe somente contra despedidas em razão da prática de atividades sindicais, mas também contra qualquer ato que discrimine empregados, como suspensões, transferências ou modificações prejudiciais nas condições de trabalho.

No Brasil existe também a previsão de garantia de emprego a empregados que exerçam cargo de representação sindical ou administração profissional, inclusive junto a órgãos de deliberação coletiva, mesmo que sejam suplentes. A garantia impossibilita a dispensa dos empregados desde o momento do registro de sua candidatura ao cargo e, caso logre vencer as eleições, em até um ano após o término do mandato. Ademais, fica proibida a transferência do local de trabalho, ou outras práticas que obstem o exercício das atividades sindicais. 
Com a ratificação da Convenção 135 da OIT, a garantia provisória de emprego também é assegurada aos representantes de empregados nas empresas com mais de duzentos trabalhadores. Os delegados sindicais, que no Brasil possuem regulamentação própria (artigo 523 da Consolidação das Leis do Trabalho), muitas vezes atuam em diversas empresas e se contrapõem diretamente ao(s) empregador(es); paradoxalmente, para estes não é prevista quaisquer garantias (seja quanto à mantença do emprego, seja quanto à inamovibilidade).

Outra concepção importante é a de práticas desleais, desenvolvida pelo direito norteamericano (especialmente a National Labor Relations Act, de 1935, também conhecida como Lei Wagner). Compreende-se como antissindical o empregador interferir, controlar ou coagir os seus empregados quanto ao exercício de direitos sindicais legalmente garantidos. Ademais, o empregador interferir na formação ou administração de qualquer sindicato, com ele contribuir financeiramente ou dar-lhe qualquer outro tipo de ajuda fere a independência do ente representativo e, por isso, configura-se a antissindicalidade.

Também esta lei considerou conduta antissindical discriminar trabalhadores quanto a empregar, manter o emprego, ou estabelecer outra condição qualquer para encorajar ou desencorajar empregado a tornar-se ou deixar de ser membro de sindicato, por razões bastante óbvias: sendo o empregado membro do sindicato, poderia começar a desenvolver comportamento contrário aos interesses do empregador no ambiente do trabalho, assim como influenciar seus pares. Dispensar um empregado, ou discriminá-lo, em razão de este reclamar ou testemunhar em procedimento relacionado a práticas antissindicais é procedimento igualmente tipificado na legislação em análise.

Recusar-se o empregador em negociar coletivamente com os representantes dos seus empregados é também conduta antissindical. Assim, o empregador deverá negociar de boa-fé, ou seja, deverá procurar todas as formas possíveis de verdadeiramente contratar coletivamente com o sindicato. A sua recusa, ou um somatório de atitudes a demonstrar não ser esta a real intenção do empregador, que em verdade deseja tergiversar ou simular o atendimento aos interesses empregatícios, permite aferir comportamento de prática desleal (CUNHA, 2006, p. 122-123).

Em 1947, no imediato pós-guerra, fez-se sentir a reforma conservadora das relações sindicais presente no Taft-Hartley Act, de 1947. À época, a prosperidade da atividade sindical alcançada após a edição da Lei Wagner era notória, e o Taft-Hartley Act tencionou frear tais conquistas. Houve imposição da obrigação de negociar de boa-fé também ao sindicato dos trabalhadores, o que parece de per si algo estranho, já que é interesse da entidade sindical dos empregados não se furtar à negociação, sempre buscando melhores condições de trabalho. $\mathrm{O}$ mesmo interesse nem sempre se dá quanto ao empregador. Ademais, proibiu-se a prática da greve em que os empregados sitiem a empresa durante o curso do movimento, visando proteger (como valor cimeiro) a propriedade do empregador contra a ocupação promovida.

A lei também proibiu que altos empregados, com cargo de supervisão na empresa, pudessem desenvolver atividades sindicais, além de exigir, dos dirigentes sindicais, que professassem fé anticomunista (KAUFMANN, 2005, p. 278). A visão liberal do Taft-Hartley Act visava proteger a liberdade individual do empregado contra os atos de seu próprio sindicato, também buscando a proteção do empregador contra determinadas exigências sindicais, como estabelecer ou favorecer a contratação de empregados sindicalizados. Tornou bilateral a possibilidade de interferência sindical, passando a prever a figura dos empregados que pudessem exercer algum tipo de ingerência contra sindicatos patronais.

Assim é a diferença apontada entre o conceito de foro sindical e o de práticas desleais: estas se apresentam como bilaterais, de maneira a garantir ética no livre jogo dos atores sociais, enquanto a noção de foro é por sua essência unilateral, de forma a beneficiar exclusivamente a figura do empregado, como explica Oscar Ermida Uriarte (1989, p. 11-12).

A CLT, em seu artigo 543, $\S 6^{\circ}$, prevê prática desleal quando a empresa visar impedir a filiação de empregado a sindicato, ou, ao contrário, o obrigue a este mister, restando por tal ato o 
empregador sujeito a sanções administrativas, sem prejuízo de outras reparações a que tiver direito o empregado.

No plano internacional, a norma fundamental em matéria de prevenção das práticas antissindicais é a Convenção de número 98, da OIT, sobre o direito de sindicalização e negociação coletiva. Neste diploma, em seu artigo $1^{\circ}$, delineiam-se atos considerados como discriminatórios, expressão também utilizada na doutrina, quando se subordina o emprego de um trabalhador à condição de não se filiar ou filiar-se a sindicato, bem como quando se dispensa um trabalhador ou o prejudica em virtude de filiação a um sindicato ou participação em atividades sindicais, fora do horário do trabalho ou mesmo em jornada, com o consentimento do empregador.

A legislação brasileira também proíbe a discriminação, não apenas pelo preceito geral do artigo $3^{\circ}$ da Constituição Federal, como também por seus artigos $5^{\circ}$, I e VIII, e $7^{\circ}, \mathrm{XXX}, \mathrm{XXXI}$ e XXXII, além da Lei 9.029, de 1995. A discriminação não é vedada apenas quanto aos dirigentes, representantes ou ativistas sindicais, mas a qualquer trabalhador, seja por qual motivo for - entre estes, naturalmente, em relação a atividades de natureza sindical.

Os atos de ingerência estão explicitados em seu artigo $2^{\circ}$ da Convenção 98 da OIT. Trata-se da adoção de medidas destinadas a vedar quaisquer formas de interferência dos empregadores em organizações sindicais obreiras, o mesmo valendo para os empregados quanto às entidades de empregadores, na esteira do que foi proposto pelo modelo norte-americano de 1947. Desta forma, com Walküre Lopes Ribeiro da Silva (1993, p. 11), pode-se compreender que "os atos de discriminação correspondem em linhas gerais ao conceito amplo de foro sindical, enquanto os atos de ingerência vinculam-se à noção de práticas desleais".

\section{Atos antissindicais contra o direito de greve: breves considerações acerca da apreciação, pelo Supremo Tribunal Federal, do Recurso Extraordinário 693.456/RJ}

A greve é ainda um dos raros casos de autotutela de interesses e direitos previstos no ordenamento jurídico. Talvez por essa espontaneidade inata à greve alguns doutrinadores chegaram a considerá-la um fato social, e não jurídico. $\mathrm{Na}$ atualidade, porém, inexiste dúvida quanto à juridicidade da greve: trata-se de direito fundamental, previsto no artigo $9^{\circ}$ da Constituição Federal, que reconhece aos trabalhadores a prerrogativa de discutirem acerca da possibilidade de exercício do direito de greve, bem como definir quais interesses serão defendidos. Em síntese, ocorre greve quando os trabalhadores, coletivamente, decidem paralisar temporariamente a prestação de serviços para defender algum interesse que seja comum ao grupo (AMARANTE, 2015, p. 46-53).

Dito isto, há considerações jurídicas importantes a serem feitas. Conforme lúcida explanação do jurista lusitano Pedro Romano Martinez, o direito de greve é um instrumento corretor de desequilíbrios utilizado pelos trabalhadores, e se assemelha, com as devidas adaptações, ao aforismo rebus sic stantibus: é por meio desse movimento que se pretende alterar certas regras presentes no contrato de trabalho, vez que estas, inicialmente, poderiam ser justas logo que acertadas, mas com o decorrer do tempo tornaram-se injustas. Diante de novas circunstâncias, busca-se o reequilíbrio entre as partes; logo, conforme o autor português, "o recurso ao tribunal seria complexo, tanto no que respeita à determinação das alterações entretanto ocorridas, como na apreciação das necessidades crescentes dos trabalhadores” (2015, p. 1193). Por isto, a pressão extrajudicial mostra-se absolutamente mais ágil e eficaz.

Não há dúvidas no sentido de que a greve é, por excelência, ação sindical provavelmente a mais forte, pública e visível ação. Não por outro motivo a lei busca regulamentar seu exercício, no afã de buscar colocar-lhe limites por argumentos os mais diversos. A experiência jurídica italiana demonstra exemplarmente tal tendência: o Estatuto dos Trabalhadores, de 1970, falava sobre greve para garanti-la sem, contudo, regulamentá-la. Nos 
vinte anos que antecederam a primeira regulamentação italiana sobre greve (Lei 146, de 12 de junho de 1990), o Judiciário apressou-se em classificá-las, muitas vezes, como "anômalas" ou causadoras de mal-estar social, por prejudicar interesses de terceiros. A solução encontrada foi exigir a tentativa de negociação coletiva como pré-condição ao exercício do direito de greve (CARINCI et al, 2013, p. 344-345).

O Judiciário trabalhista brasileiro, em sua instância máxima - Tribunal Superior do Trabalho - demonstrou reiterada prática, por meio da Orientação Jurisprudencial 01 da Seção de Dissídios Coletivos (cancelada em 2004), de desrespeito até mesmo à Lei de Greve. A Orientação Jurisprudencial considerava abusiva greve deflagrada em razão da inobservância do cumprimento de norma coletiva em vigor. A própria Lei 7.783/89, em seu artigo 14, parágrafo único, I, estatui não ser abusivo deflagrar greve que tenha, por objeto, o cumprimento de cláusula negocial coletiva.

A Orientação Jurisprudencial 11 da Seção de Dissídios Coletivos, ainda vigente, torna imprescindível a tentativa de negociação coletiva "pacífica" que reste frustrada como condição para que a greve não seja considerada abusiva. Nas escorreitas considerações de Thiago Barison (2016, p. 203), o Tribunal "identifica a greve ao conflito e a negociação à paz" e, nessa falsa dicotomia (ou maniqueísmo), o Judiciário mostra-se rigorosamente refratário ao que estabelece a própria Constituição Federal.

Um dos Ministros dessa Corte Trabalhista chega a afirmar que o direito fundamental de greve, qual previsto no artigo $9^{\circ}$ da Constituição Federal, possui redação quase irresponsável, por (aparentemente) permitir deflagrar-se greve sem restrições, bastando, para tanto, verificar a oportunidade e critério apontado pela coletividade dos trabalhadores. Logo, deve o direito fundamental ao exercício da greve como instrumento de tutela dos interesses trabalhistas sofrer restrições e forte tutela intervencionista do Estado, máxime pelo Poder Judiciário; em relação à negociação coletiva, porém, a postura desse mesmo Estado é liberal, buscando-se interferir o mínimo possível no que os atores sociais decidem adotar como normas coletivas.

Embora negociação coletiva e greve componham dois dos diversos e múltiplos pilares que sustentam a liberdade sindical, o tratamento entre eles é diverso. Questiona-se até mesmo se a greve poderá ter objetivo outro que não discutir questões estritamente relacionadas à profissão.

Nesse particular, Maria do Rosário Palma Ramalho (2012) reconhece que a Constituição Portuguesa não estabelece essa limitação, pois confere aos trabalhadores definir quais os objetivos da greve; desta forma, até mesmo greves por motivos políticos poderiam existir. Todavia, rechaça tal possibilidade, já que todo direito está sujeito a limitações, ainda que implícitas. Invoca, no afã de sustentar tal tese, a figura do abuso do direito, previsto no Código Civil lusitano. No Brasil, Maurício Godinho Delgado (2016), embora admita a licitude de a greve não se restringir apenas a questões profissionais (pois seria reduzir o comando constitucional), reconhece que a doutrina e a jurisprudência majoritária tende a seguir os argumentos apontados pela tratadista de além-mar.

Sem qualquer dúvida, tem-se em tudo quanto até aqui foi narrado densa e grave conduta antissindical por parte do Estado - ou, mais especificamente, do Poder Judiciário. Costuma-se elencar, com mais facilidade, atos que o empregador possa cometer contra empregados que se ligaram a movimentos grevistas. Dispensa sem justa causa no período imediatamente pós-greve, represálias pela participação no movimento ou divulgação de "listas sujas", com a finalidade de tisnar a imagem de empregados que se envolvam com greve são exemplos comuns (MARTINEZ, 2013). Todavia, não apenas os entes privados, mas também o próprio Estado poderá promover atos antissindicais, seja contra os empregados da iniciativa privada, seja em desfavor de servidores públicos.

Nesse sentido, pode-se afirmar ter havido grave retrocesso social na decisão tomada pelo Supremo Tribunal Federal (STF) quando do julgamento do Recurso Extraordinário 693.456/RJ, que exala forte antissindicalidade. Tratava-se de Recurso Extraordinário interposto pela FAETEC 
(Fundação de Apoio à Escola Técnica), ente público do Rio de Janeiro, que objetivava discutir a legalidade de não pagar salário aos seus servidores enquanto estes participassem de movimento grevista. Por maioria, a Suprema Corte de Justiça do Brasil admitiu tal prática, determinando, a partir de então, que seja efetuado desconto no pagamento de salário de quaisquer servidores públicos que venham a exercer seu direito fundamental de greve quanto ao tempo em que o trabalhador permanecer em movimento paredista.

O Tribunal, por maioria, adotou a tese de que a Administração Pública deve (e não pode) proceder ao desconto dos dias de paralisação decorrentes do exercício do direito de greve pelos servidores públicos, pois há suspensão do vínculo funcional entre estes e o Poder Público. Ressalva que não deverá haver descontos caso a Administração Pública cometa conduta ilícita, não mencionando exceção quando haja greve lícita por parte dos servidores (BRASIL, 2016, p. 75). Tal argumento - o da suspensão do vínculo administrativo, ou do contrato individual de trabalho - tem servido como fundamento, ao longo da História, para a prática sistemática de atos antissindicais, consoante se verá.

$\mathrm{O}$ argumento utilizado para que o empregador (mesmo em sendo o Estado), unilateralmente, venha a efetuar descontos no salário dos trabalhadores em greve é que, durante a paralisação dos trabalhos, ocorre a suspensão do contrato de trabalho já mencionada. Logo, inexiste reciprocidade das obrigações básicas: quem toma serviços não pode exigi-los de quem os presta e, em contrapartida, cessa o dever patronal - ou da Administração Pública - de pagar pelo serviço prestado.

Nota-se que, em se tratando de greve, a decisão do STF considera iguais o servidor público e a Administração, vez que a decisão citada diz respeito a greves no serviço público. A situação, porém, é a mesma pela qual, na iniciativa privada, empregados grevistas sentem em seus bolsos quando deflagram greve em face de seus empregadores; por mais antijurídica que inicialmente possa parecer a questão descrita, ela obtém justificativa na própria formulação jurídica do direito de greve.

Já se disse, em passant, que por considerável tempo a greve foi vista apenas como fato social, desprovido de juridicidade. Para que o direito de greve merecesse reconhecimento foi preciso qualificá-lo, pois, como ato jurídico, que requer objeto válido (fins perseguidos por meio da greve), vontade de parte capaz (em especial a coletividade dos trabalhadores, consubstanciada na figura do ente sindical) e forma de exercício prevista em lei.

Vista como mero fato social, a greve não produzia efeitos jurídicos: os empregadores e também os trabalhadores que não aderissem ao movimento permaneciam como estavam, ou seja, em relações intactas, mantendo-se a prestação de serviços e o correspondente pagamento de salários. Os trabalhadores grevistas, nesta ótica liberal, poderiam ser substituídos sem que tal atitude configurasse qualquer ato antissindical. Seria possível, é claro, que a prestação de serviços acabasse por cessar completamente em face da alta ou total adesão dos trabalhadores à greve, mas isto se dava por razões de fato, e não de direito.

No momento em que há direito de greve, exige-se que o movimento grevista satisfaça os requisitos materiais e formais ínsitos ao ato jurídico. A partir deste marco é que se poderá avaliar, até mesmo judicialmente, se a greve é lícita ou não, e se está apta - na clássica teoria civilista dos atos jurídicos - a criar, modificar ou extinguir direitos, como bem explica Néstor de Buen Lozano (2002, p. 889-896). Surge, a partir da pacificação do conflito, o novo instrumento coletivo que regerá as relações entre empregadores e empregados, ou seja, o negócio jurídico que se materializa no acordo ou na convenção coletiva de trabalho.

Diante desta formulação, que remonta às primeiras décadas do século $\mathrm{XX}$, foi possível sustentar que, durante o curso de movimento grevista, as relações contratuais entre empregados e empregadores restavam suspensas em seus efeitos principais. Não se poderia computar o período no qual o trabalhador permaneceu em greve como falta ao trabalho, afinal, o subordinado estava a exercer licitamente seu direito de natureza sindical: abster-se de trabalhar, no afã de pressionar 
quem lhe toma serviços a ceder aos reclamos coletivos da categoria. Lado outro, como decorrência lógica do que foi citado, cessa para o empregador a obrigatoriedade de pagar salários a quem momentaneamente deixa de prestar-lhe serviços. Se a greve tem como escopo a celebração de um negócio jurídico, certo é que ambas as partes possuem direitos e deveres recíprocos, devendo realizar, igualmente, recíprocas concessões.

A fórmula jurídica citada acaba por tornar-se contraditória. Na Itália, por exemplo, a visão liberal dos direitos sindicais permite afirmar que o empregador não pode impedir que seu empregado venha a exercer atividades sindicais, ainda que em horário de trabalho, pois tal proibição poderá causar-lhe sanções civis e, eventualmente, criminais. Todavia, deflagrado o movimento grevista - ainda que não haja lei prevendo a suspensão remuneratória - tornou-se, na jurisprudência do país em comento, a possibilidade de o empregador deixar de pagar salários(GHERA, 2012, p. 158). Em Portugal há previsão expressa quanto à suspensão do pagamento de salários, fato que, na precisa observação de António Monteiro Fernandes (2014, p. 855), "não se ajusta linearmente às características da situação que se estabelece com o exercício da greve"

A Lei 7.783/89, que regulamenta o exercício da greve no setor privado brasileiro, estabelece em seu artigo $7^{\circ}$ que a greve suspende o contrato individual de trabalho. Caso sejam observados os consolidados artigos 471 a 476-A da Consolidação das Leis do Trabalho (CLT), nota-se a existência das figuras da interrupção e da suspensão do contrato individual de trabalho, sem esclarecer ao certo o que estas significam. Bem por isso, Homero Batista Mateus da Silva (2015) compreende que, ao considerar-se o artigo 473 da CLT como interrupção do contrato de trabalho (o empregado não presta serviços ao empregador, mas o salário lhe é devido), ou o artigo 476 do mesmo diploma como suspensão contratual (não há prestação de serviços ao empregador, e este não é obrigado a pagar salários), delega-se à doutrina a tarefa de identificar qual dos dois institutos deverá incidir no caso concreto.

Promulgada nos tempos da ditadura militar, a Lei 4.330/64, que regulamentava a greve no Brasil, estatuía em seu artigo 20, parágrafo único, que a deflagração do movimento grevista, desde que lícito, suspendia o contrato de trabalho, sendo, porém, devido o pagamento de salários aos empregados grevistas. Tratava-se, portanto, de interrupção do contrato de trabalho. A legislação de 1989 deixa em aberto a questão; logo, os salários que seriam pagos durante o período da greve poderão ser objeto de reivindicação durante negociação coletiva, laudo arbitral ou dissídio coletivo, o que fragiliza ainda mais o poder de negociação dos sindicatos. $\mathrm{O}$ salário devido ao longo do período do movimento grevista, já retido unilateralmente pelo empregador, será automaticamente mais uma das reivindicações dos trabalhadores a serem discutidas $e$ negociadas mediante concessões recíprocas.

Não se admite mais a greve, porém, como ato jurídico. Em que pese o direito comum ser fonte subsidiária do direito trabalhista (artigo $8^{\circ}$, parágrafo único, CLT), este somente será aplicado se não for incompatível com os princípios do direito do trabalho. Esse ramo jurídico possui métodos e interpretação próprios, pois se modifica rápida e constantemente na complexidade ínsita à relação capital-trabalho. Para isso, o ordenamento nem sempre tem pronta resposta para que o direito do trabalho cumpra com seu dever, que é o de melhorar as condições sociais do trabalhador (SOUTO MAIOR, 2000, p. 303-304).

Malgrado não tenha o Brasil ratificado a Convenção 87 da OIT, que é o vetor da liberdade sindical mundo afora, o Decreto 591/92 promulgou o Pacto Internacional sobre Direitos Econômicos, Sociais e Culturais. Em seu artigo $8^{\circ}$, resta claro que a liberdade sindical deve ser ampla, sem limitações outras que não sejam aquelas necessárias à garantia da segurança do país e da preservação do direito de terceiros; no mais, garante o direito de greve, exercido conforme as leis do país.

Consoante visto neste estudo a greve, conceitualmente, é uma das formas de ação sindical. Sua norma maior é o artigo $9^{\circ}$ da Constituição Federal, que dirige aos trabalhadores - e 
não aos empregadores - escolher a conveniência de exercê-la, proibindo abusos que serão definidos em lei. A greve, em si, não é abuso do direito, mas é assim considerada quando se aplica o inconstitucional artigo $7^{\circ}$ da Lei 7.783/89 para legitimar a ausência de pagamento de salários durante o curso do movimento paredista. Tal artigo é refratário ao princípio constitucional da liberdade sindical, além de constituir-se em clara afronta ao princípio da norma mais favorável, tanto quando de sua formulação legislativa, quanto no momento em que se poderia aplicar norma mais benéfica ao trabalhador.

O artigo $9^{\circ}$ da Constituição Federal, como visto, é norma de direito fundamental. Ademais, direitos previstos em tratados internacionais de direitos humanos têm hierarquia superior à legislação infraconstitucional, ostentando a condição sui generis de norma supralegal: assim ocorre, sem dúvidas, com o Decreto 591/92.

Fosse o citado Decreto posterior ou anterior à redação do artigo $7^{\circ}$ da Lei 7.783/89, invalidaria a malsã interpretação de que a suspensão prevista nesse artigo impede o direito à percepção de salários pelos empregados grevistas, por ferir claramente ação que se situa no âmbito de proteção das liberdades sindicais. No mais, face à proibição de retrocesso, nenhuma alteração legislativa pode revogar conquistas já estabelecidas (MENDES; BRANCO, 2015, P. 148-149). Andou mal o legislador, portanto, quando da redação do artigo $7^{\circ}$ da Lei 7.783/89, posterior à Constituição Federal de 1988, caso se compare o conteúdo do artigo em comento com o texto da Lei 4.330/64, em seu artigo 20, parágrafo único, tendo-se em consideração o retrocesso causado.

A questão mais grave a ser enfrentada, porém, já foi citada no item 1 do presente estudo: vive-se, atualmente, na sociedade salarial, como bem pontua Robert Castel (1998). Até mesmo profissionais liberais, pequenos empresários e trabalhadores informais sustentam-se unicamente por meio de seu trabalho pontual e direto, ao qual genericamente pode dar-se o nome de "salário". Caso a crítica ao sistema sindical se dê pela exclusão desses novos arranjos do capital no sistema do sindicalismo centrado na prestação subordinada de serviços, como pontua Oton de Albuquerque Vasconcelos Filho (2008, p. 109-110), a antissindicalidade mostra-se ainda mais densa.

Todavia, ainda que se considere apenas o sistema sindical vigente, admitir a possibilidade de corte de salários dos trabalhadores grevistas impede sua sobrevivência material. Ninguém poderá valer-se da greve como meio de pressão contra o empregador, reivindicando condições mais justas de trabalho, se é por meio da remuneração percebida que o trabalhador sustenta a si mesmo e à sua família.

Deixar de pagar salários ao trabalhador por este participar de uma legítima ação sindical, qual seja, a greve, impõe-lhe o fardo de, para conquistar melhores condições de trabalho venha a submeter-se, muitas vezes, a determinada condição pessoal que se poderia denominar préfamélica. Mesmo que, em negociação coletiva, salários de trabalhadores grevistas sejam pagos retroativamente, ninguém se alimenta de forma retroativa. Esta, provavelmente, é uma das principais razões pelas quais os movimentos grevistas no setor privado têm se tornado quase que inexistentes (RODRIGUES, 1999).

A decisão do Supremo Tribunal Federal citada neste tópico, porém, refere-se a servidores públicos. É sabido que a Constituição Federal, em seu artigo 37, VII, reconhece direito de greve aos servidores públicos civis, mas remete sua regulamentação a lei específica. $\mathrm{O}$ Supremo Tribunal Federal, tendo em vista a ausência de formulação de lei mesmo vários anos após a promulgação do texto constitucional, reconheceu mora legislativa e, por meio dos Mandados de Injunção 670/ES, 708/DF e 712/PA, mandou que seja aplicado, por ora, quanto à greve no setor público, o diploma previsto para o setor privado (BARROS, 2016, p. 855).

No que respeita ao funcionalismo público, em 2010 o Brasil ratificou a Convenção 151 e a Recomendação 159 da Organização Internacional do Trabalho, as quais versam sobre as relações de trabalho na Administração Pública e preveem o direito dos trabalhadores do setor 
público à liberdade sindical em sentido amplo, conforme artigos $4^{\circ}$ e $5^{\circ}$ deste diploma. O Decreto 7.944/2013 promulgou a Convenção e a Recomendação acima mencionadas, completando o procedimento necessário para que elas produzissem efeitos no Brasil.

Com mais razão ainda, a legislação internacional citada, que possui o caráter sui generis de norma supralegal, não admite qualquer conduta atentatória à liberdade sindical. Não há nenhuma previsão expressa em texto de lei que permita, à Administração, descontar o salário de servidores públicos em greve; ainda assim, no discurso do Supremo Tribunal Federal, o ente público tem o dever - e não a mera faculdade - de descontar salário dos servidores grevistas, remetendo a devolução do valor retido como possível questão a ser negociada com o Poder Público.

Desta forma, o Estado, inicialmente pelos longos braços dos Poderes Legislativo e Executivo, cometeu conduta antissindical ao prever suspensão do trabalho durante o período de greve no artigo $7^{\circ}$ da Lei 7.783/89 sem explicitar que nessa "suspensão" (a qual deveria ser interpretada como interrupção dos efeitos contratuais) o pagamento de salário seria devido. Muito mais grave, porém, é a conduta antissindical tomada pelo STF, que é a instância máxima da interpretação constitucional do país.

Ao abandonar a tradição garantista do Tribunal, a Suprema Corte do Brasil adentrou no espinhoso terreno do liberalismo político-econômico, de maneira a tratar servidores públicos e Administração como partes iguais, com idêntica possibilidade de negociação. Mais ainda: determinou o desconto salarial dos grevistas como dever da Administração Pública, de forma tal a prejudicar a adesão de trabalhadores em legítimos movimentos grevistas. Noutro dizer, fere a liberdade sindical quando impõe, ao servidor público, o ônus de arcar com a ausência de pagamento durante a greve e, desta forma, torna-o responsável por eventuais prejuízos causados à sua própria alimentação, além das obrigações diversas que possui, face ao exercício de um direito fundamental.

\section{CONCLUSÃO}

Parece inegável que, na sociedade salarial, tal como se conhece atualmente, o corte de salários de servidores que deflagram greve em desfavor da Administração Pública, a fim de que esta promova melhorias nas condições de trabalho, possui a nítida finalidade de intimidar trabalhadores a não aderirem ao movimento.

A assertiva encontra embasamento que não é difícil de ser constatado: seja na iniciativa privada ou no setor público, é ainda nítida a fragilidade do sindicalismo brasileiro. A Constituição Federal manteve o sistema da unicidade sindical, absolutamente refratário à liberdade sindical em sentido amplo, como defende a Organização Internacional do Trabalho (OIT). O documento máximo acerca deste tema, que é a Convenção 87 da OIT, não foi ratificado pelo Brasil até a atualidade.

Os sindicatos de base cada vez mais perdem a capacidade gregária de unir trabalhadores para a luta por interesses coletivos, dada a fragmentação das atividades produtivas e o capital que livremente circula pelo mundo globalizado. As figuras sindicais, ainda presas ao âmbito nacional, recebem proteção pontual da legislação que, contudo, é inábil a combater a antissindicalidade presente em diversas esferas. Se a conduta antissindical é o ataque frontal e direto à liberdade sindical, percebe-se que não existe sequer a possibilidade de prever quantas e quais serão as atitudes do empregador ou do Estado que possam limitar esse direito fundamental.

A greve, ou o exercício do direito de greve, em que pese integrarem o rol das atividades sindicais, são ainda vistos como "mal" a ser combatido pela "boa" negociação coletiva, que, no plano das ideias, simboliza a ideologia da concórdia entre capital e trabalho. Greve é o acirramento ou a tensão entre esses dois fatores produtivos na visão até mesmo do Judiciário brasileiro, que não percebe sua verdadeira natureza. Da mesma forma que a febre não é em si 
mesma uma doença, e sim o sintoma de alguma moléstia, a greve não é o elemento bélico na relação entre capital e trabalho, mas apenas sua manifestação mais explícita.

$\mathrm{O}$ direito do trabalho, concebido na sociedade capitalista como instrumento para a construção de uma democracia social, possui interpretação, métodos e regras próprios. As velhas fórmulas civilistas, se um dia influenciaram a formação do direito trabalhista, hoje impedem sua evolução. Não há como categorizar a greve em qualquer instituto do direito comum, tendo em vista suas peculiaridades no campo da ação sindical que, frise-se, deve ser a mais livre possível.

A visão da greve como suspensão do contrato individual de trabalho não significa e jamais significou, de forma automática, a prerrogativa de o empregador descontar salários de seus subordinados, unilateralmente, quando em curso determinado movimento grevista. Essa visão autoritária foi construída ao longo de muitos anos pelo Tribunal Superior do Trabalho e, mais recentemente, ganhou respaldo no Supremo Tribunal Federal no que respeita às relações entre a Administração e seus servidores. Mais ainda: vincula a Administração pública à observância da decisão tomada, o que representa grave retrocesso social.

Revendo-se a metodologia própria do direito do trabalho, não se consegue chegar a outra conclusão senão a de que a Suprema Corte do Brasil acaba por patrocinar, na decisão do Recurso Extraordinário 693.456/RJ, conduta antissindical por parte do Estado. Sem direito a perceber remuneração, o servidor tende a permanecer estático diante da dinâmica sindical, já que teria de abrir mão do seu único meio individual de subsistência em prol de interesses que, apesar de serem coletivos, não permitem ao trabalhador atender à sua necessidade primeira: alimentarse. A liberdade sindical acaba por ser afetada em uma de suas principais formas de ação, qual seja, a greve, em virtude de decisão oriunda do Supremo Tribunal Federal.

$\mathrm{Na}$ iniciativa privada ou no setor público há, por assim dizer, certa classe (ou "casta") de empregados ou servidores públicos bem remunerada. Percebem valores mensais superiores a 40 (quarenta) salários mínimos nacionais, por exemplo. Para tais trabalhadores, de fato, é possível que haja greve e corte de salários sem que se prejudique sua subsistência: tais empregados ou servidores possuem meios para manterem-se em bom espaço de tempo sem receber o valor de seu contracheque. A grande massa de trabalhadores e servidores públicos, porém, vive no limiar da navalha: qualquer tropeço ou mau passo - como perder um mês inteiro de salários - poderá comprometer todos os compromissos financeiros do trabalhador. Como se falar, diante de situações-limite como estas, em greve como direito fundamental? Com a palavra, a antissindical decisão presente no Recurso Extraordinário 693.456/RJ.

\section{REFERÊNCIAS BIBLIOGRÁFICAS}

ALONSO OLEA, Manuel. Derecho del Trabajo. 27. ed. Madrid: Civitas, 2009.

AMARANTE, João Armando Moretto. Lei de Greve Comentada. São Paulo: Almedina, 2015.

AROUCA, José Carlos. Curso básico de Direito Sindical. 3. ed. São Paulo: LTr, 2012.

BARISON, Thiago. A estrutura sindical de Estado no Brasil e o controle judiciário após a Constituição de 1988. São Paulo: LTr, 2016.

BARROS, Alice Monteiro de. Curso de Direito do Trabalho. 10. ed. São Paulo: LTr, 2016.

BOBBIO, Norberto. A Era dos Direitos. Trad. Regina Lyra. Rio de Janeiro: Campus, 2004. 
BONAVIDES, Paulo. Curso de Direito Constitucional. 31. ed. São Paulo: Malheiros, 2016.

CAMERLYNCK, Guillaume Henri; LYON-CAEN, Gérard. Précis de Droit du Travail. 5. ed. Paris: Dalloz, 1972.

CARINCI, Franco; TAMAJO, Raffaele de Luca; TOSI, Paolo; TREU, Tiziano. Il Diritto del Lavoro: il diritto sindacale. 6. ed. Roma: UTET Giuridica, 2013.

CASTEL, Robert. As metamorfoses da questão social: uma crônica do salário. Trad. Iraci D. Poleti. Petrópolis: Vozes, 1998.

CUNHA, Tadeu Henrique Lopes da. Proteção contra atos anti-sindicais. in: SANTOS, Enoque Ribeiro dos; SILVA, Otávio Pinto e. Temas controvertidos do Direito Coletivo do Trabalho no cenário nacional e internacional. São Paulo: LTr, 2006. p. 115-140.

DE BUEN LOZANO, Néstor. Derecho del Trabajo. 16. ed. v. 2. México: Porrúa, 2002.

DELGADO, Maurício Godinho. Curso de Direito do Trabalho. 15. ed. São Paulo: LTr, 2016.

ECHEVERRIA, Bernardo Van Der Laat. De las practicas antisindicales: especial referencia a la legislacion de Centroamerica y Panama. Revista de Ciencias Jurídicas, Costa Rica, n.57, p. 135157, may/ago. 1987.

ERMIDA URIARTE, Oscar. A proteção contra os atos anti-sindicais. São Paulo: LTr, 1989.

FERNANDES, António Monteiro. Direito do Trabalho. 17. ed. Coimbra: Almedina, 2014.

FERRAZ JUNIOR, Tércio Sampaio; DINIZ, Maria Helena; GEORGAKILAS, Ritinha A. Stevenson. Constituição de 1988: Legitimidade, Vigência e Eficácia, Supremacia. São Paulo: Atlas, 1989.

GERNIGON, Bernard; ODERO, Alberto; GUIDO, Horacio. Principios de la OIT sobre el derecho de huelga. Revista Internacional del Trabajo, Ginebra, v.117, n.4, p. 473-515, 1998.

GHERA, Edoardo. Diritto del Lavoro: Il rapporto di lavoro. 17. ed. Bari: Cacucci, 2012.

KAUFMANN, Marcus de Oliveira. Das práticas anti-sindicais às práticas anti-representativas: sistemas de combate e a tutela de representações coletivas de trabalhadores. São Paulo: LTr, 2005.

MARTINEZ, Luciano. Condutas antissindicais. São Paulo: Saraiva, 2013. 
MARTINEZ, Pedro Romano. Direito do Trabalho. 7. ed. Coimbra: Almedina, 2015.

MENDES, Gilmar Ferreira; BRANCO, Paulo Gustavo Gonet. Curso de Direito Constitucional. 10. ed. São Paulo: Saraiva, 2015.

MORAES FILHO, Evaristo de. Do delito ao direito de greve. Rio de Janeiro: Serviço de Documentação do Ministério do Trabalho, Indústria e Comércio, 1956.

. Introdução ao Direito do Trabalho. v. 1. Rio de Janeiro: Forense, 1956.

NASCIMENTO, Amauri Mascaro; NASCIMENTO, Sônia Mascaro; NASCIMENTO, Marcelo Mascaro. Compêndio de Direito Sindical. 8. ed. São Paulo: LTr, 2015.

PALMA RAMALHO, Maria do Rosário. Tratado de Direito do Trabalho: situações laborais colectivas. v. 3. Coimbra: Almedina, 2012.

PIMENTA, Raquel Betty de Castro. Condutas antissindicais praticadas pelo empregador. São Paulo: LTr, 2014.

PIOVESAN, Flávia. Direitos Humanos e o trabalho. in: FREITAS JUNIOR, Antônio Rodrigues de (org.). Direito do Trabalho, Direitos Humanos. Leme: Editora BH, 2006.

RODRIGUES, Leôncio Martins. Destino do sindicalismo. São Paulo: Edusp, 1999.

ROMAGNOLI, Umberto. La libertad sindical, hoy. Revista de Derecho Social, v.4, n. 14, p. 923, abr./jun. 2001.

SCOGNAMIGLIO, Renato. Diritto del Lavoro. 2. ed. Bari: Laterza, 2005.

SILVA, Homero Batista Mateus da. Curso de Direito do Trabalho aplicado: contrato de trabalho. 3. ed. v. 6. São Paulo: Revista dos Tribunais, 2015.

SILVA, Sayonara Grillo Coutinho Leonardo da. O reconhecimento das centrais sindicais e a criação de sindicatos no Brasil: antes e depois da Constituição de 1988. in: HORN, Carlos Henrique; SILVA, Sayonara Grillo Coutinho Leonardo da. Ensaios sobre sindicatos e reforma sindical no Brasil. São Paulo: LTr, 2009. p. 15-58.

Relações coletivas de trabalho: configurações institucionais no Brasil contemporâneo. São Paulo: LTr, 2008.

SILVA, Walküre Lopes Ribeiro da. Liberdade sindical no contexto dos Direitos Humanos: a experiência da OIT. Revista do Departamento de Direito do Trabalho e da Seguridade Social da Faculdade de Direito da USP, São Paulo, v. 1, n. 1, p. 205-222, jan./jun. 2006. 
- Repressão penal dos atos anti-sindicais no direito brasileiro e italiano. Boletim do Centro de Estudos da Procuradoria Geral do Estado de São Paulo, São Paulo, v.17, n.5, p. 1013, mai. 1993.

SIQUEIRA NETO, José Francisco. Liberdade sindical e representação dos trabalhadores nos locais de trabalho. São Paulo: LTr, 2000.

SOUTO MAIOR, Jorge Luiz. O direito do trabalho como instrumento de justiça social. São Paulo: LTr, 2000.

SOUZA, Michelle Amorim Sancho Souza. Conceito constitucional da dignidade coletiva $e$ efetivação dos direitos sociais. Porto Alegre: Sérgio Antônio Fabris, 2015.

VALTICOS, Nicolas. Derecho Internacional del Trabajo. Trad. Maria José Triviño. Madrid: Tecnos, 1977.

VASCONCELOS FILHO, Oton de Albuquerque. Liberdades sindicais e atos anti-sindicais. São Paulo: LTr, 2008. 